\title{
The normative problem of merit goods in perspective
}

\author{
Maxime Desmarais-Tremblay ${ }^{1}$ \\ Centre for Philosophy of Natural and Social Science, London School of Economics, Houghton \\ Street, London WC2A 2AE, UK. Centre Walras-Pareto, Université de Lausanne, Switzerland. \\ Centre d'Économie de la Sorbonne, Université Paris 1 Panthéon-Sorbonne, France.
}

(April 2016)

\begin{abstract}
In his Theory of Public Finance (1959), Musgrave invented the concept of merit wants to describe public wants that are satisfied by goods provided by the government in violation of the principle of consumer sovereignty. Starting from Musgrave's mature discussion (1987), I construct two categories to classify the explanations of merit goods. The first strand of thought attempts to justify merit goods within New welfare economics, by modifying its assumptions to accommodate irrationality, uncertainty, lack of information, and psychic externalities. The second category encompasses more radical departures from consumer sovereignty, drawn from philosophical critiques of economics. In the third part of the paper, I argue that the two strands might be represented by a nonindividualistic social welfare function. I also show how this solution echoes Musgrave's (1937) early views on public expenditures before he coined the concept of merit wants. From an historical perspective, the survival of the concept highlights the persistence of a social point of view in welfare economics.
\end{abstract}

Keywords: merit wants, merit goods, Richard A. Musgrave, consumer sovereignty JEL classifications: H40, B29, B40, A13

\footnotetext{
1 maxime.desmarais-tremblay@unil.ch.
} 


\section{INTRODUCTION}

The concept of merit wants was invented by the German-born American economist Richard A. Musgrave for his Theory of Public Finance (1959). In a convoluted way, he meant to say that some human needs were of such importance that they merited governmental support in the form of in-kind distribution of specific goods - merit goods - such as housing for the poor, school lunches, and healthcare. Musgrave argued that social goods - or collective, or public goods as they are often called - had to be provided by the government because they were technically non-excludable. This feature would lead selfish individuals to free ride if the goods were allocated by the market. Yet, merit goods evaded this technical market-failure logic. Musgrave (1959) claimed that "a different type of intervention occurs where public policy aims at an allocation of resources which deviates from that reflected by consumer sovereignty." In his Theory, he conceptualized the economic functions of the government as being in three branches: allocation, distribution, and stabilization. The distribution branch would redistribute income and wealth to the level desired by the citizens in a democracy. The allocation branch would provide social goods in line with individual preferences. Musgrave (1957) noted that transfers in kind such as elementary education pose a problem to this branch separation because they involve a redistribution motive with a decision as to what the resources would be used for. These merit wants involve a paternalistic intervention that does not respect consumer sovereignty.

The paternalistic nature of merit goods led many economists to repudiate the concept. James M. Buchanan (1960) rejected the idea of a separate distribution branch which did not reflect individual preferences. From the point of view of the individuals, merit 
goods were imposed by the government and thereby unacceptable for Buchanan (1960) who preferred to use the concept of externality to conceptualize any form of interdependency. Charles E. McLure, a former student of Musgrave's, drove the point further: "merit wants, as Musgrave defines them, have no place in a normative theory of the public household based upon individual preferences" (McLure 1968, 474). Some of the policies advocated by Musgrave under the label of merit wants are "prohibited by the ethic of the new welfare economics which Musgrave adopts" (ibid., 479). McLure argued that they constituted "a normatively empty box." Because of this methodological problem, and also because the meaning of the concept is ambiguous, it has not enjoyed the popularity of the concept of public good. As one can see in Figure 1, the concept of public goods, or collective goods, or social goods appears more frequently in scientific articles than that of merit wants or merit goods. Since both concepts were defined at about the same time in the 1950s, we can provisionally conclude that, relative to the concept of public goods, the concept of merit goods failed to achieve mainstream appeal in economics.

In spite of that, the concept of merit goods should be appealing to the student of economics for at least two reasons. The first is because merit goods are a widespread phenomenon. Everywhere in the western world, governments allocate goods that can be more accurately labeled as merit goods than as pure public goods (Fiorito and Kollintzas 2004). Second, since the concept lies in an uncomfortable place on the frontier of economics, it provides a reason to study the normative foundations of the discipline. This can be done either by challenging some assumptions at the core of neoclassical theory, or, as Peggy Musgrave $(2008,345)$ argued, by enlarging public economics to embrace the neighboring disciplines of sociology, political science, and ethics. 
Number of articles using the concepts of 'collective goods', 'public goods', or 'social goods' against those using the concepts of 'merit want(s)' or 'merit good(s)' in scientific journals (source: JSTOR DfR)

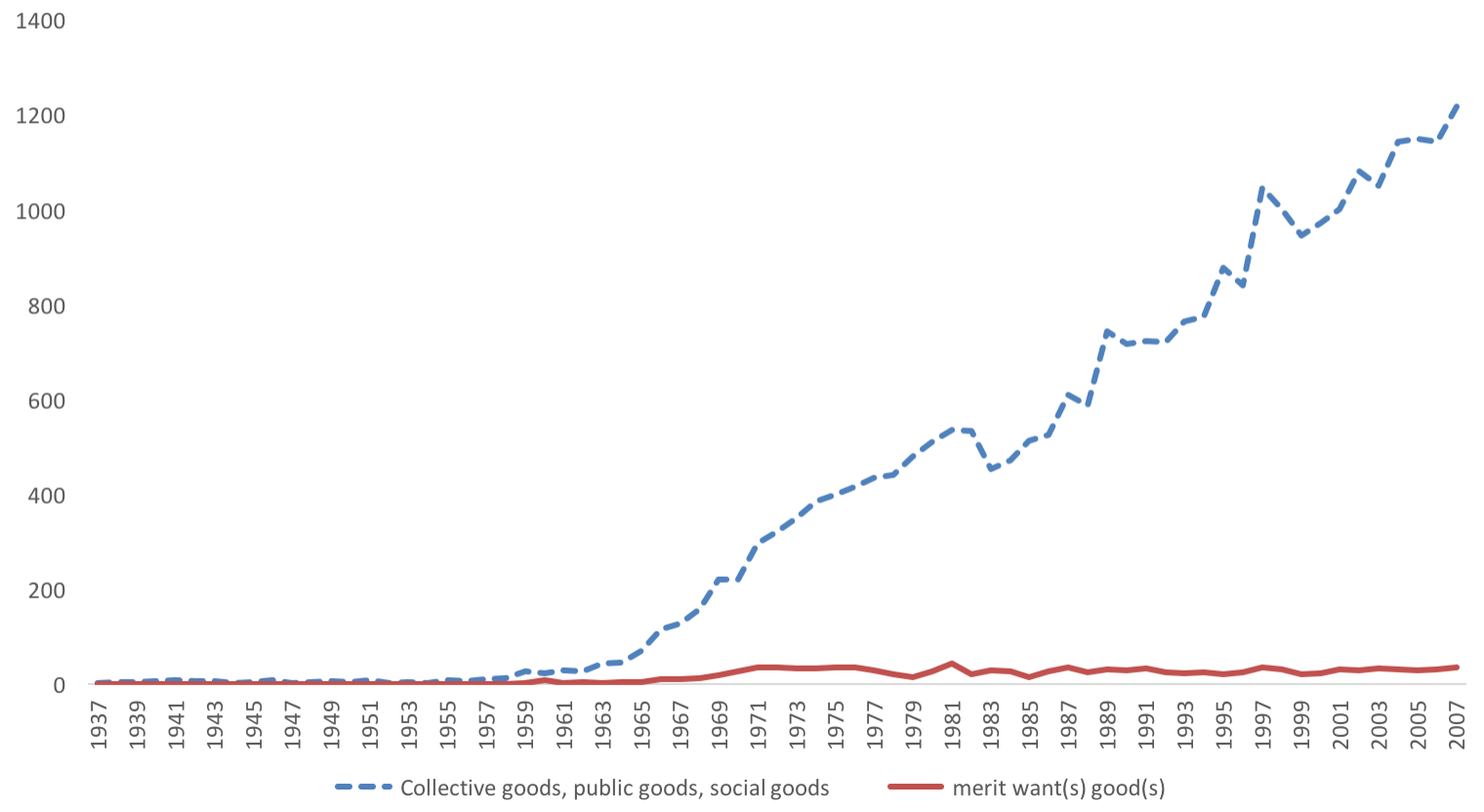

Figure 1: The relative failure of merit wants

My goal in this paper is to review the literature on the justification of the concept of merit goods by putting its normative problem into historical perspective. The different bearings on the concept reflect and participate in the evolution of welfare economics from the 1930s onwards. I show that the survival of the concept of merit goods through the decades highlights the difficulty of evading a social point of view in discussing collective welfare.

I organize the corpus in two categories: (1) the scholars who argue that merit goods can be provided by adjusting the assumptions of welfare economics; and (2) those who argue that merit wants capture socially non-reducible responsibilities of the state, thereby 
departing more forcefully from the assumptions of welfare economics. ${ }^{2}$ A discussion of these works is presented, respectively, in the first and second sections of the paper. In the third section, I ponder whether both these strands of argument can be adequately represented by the use of a non-individualistic social welfare function (SWF). I show that the SWF representation is in line with Musgrave's early conceptualization of social goods in his doctoral dissertation (1937).

In the rest of this introduction, I would like to relate my typology to Musgrave's (1987) one and also to the principle of consumer sovereignty. Musgrave (1987) wrote an entry on merit goods for the first edition of the New Palgrave Dictionary of Economics. He identified five families of arguments in favor of merit goods. First, he remarked that some commentators have defended the view that merit goods could be provided in (i) "pathological cases" when individuals do not choose what is best for them, because the choice setting is imperfect or misleading, or because of time discounting. Second, it has been argued that individuals follow the (ii) "rule of fashion." In this case, their behavior is influenced by that of others, or their choice might be influenced by advertisement. A third family of arguments has to do with (iii) "community preferences." Musgrave argued that concern for the community might lead individuals to give budgetary support to some goods although their "own preferences speak otherwise" (Musgrave 1987). He listed "concern for

\footnotetext{
2 Due to space limitations, I select only important contributions to the debate on the normative status of merit goods. For surveys focusing on different aspects, see Andel (1984); Walsh (1987); Head (1991); Ver Eecke (2007); Clément et al. (2009); Sturn (2015).
} 
maintenance of historical sites, respect for national holidays, regard for environment or for learning and the arts" as examples of such merit goods. Fourth, moral considerations might lead individuals to favor (iv) "paternalism in distribution." For instance, merit goods can be provided as 'fair shares' of some basic goods to every citizen. Finally, Musgrave notes that some have justified merit goods by resorting to thicker conceptualization of the individuals by endowing them with (v) "multiple preferences, or higher values." In terms of my typology, Musgrave's first two families of arguments fall into my first category. His third and fourth families compose my second category. His fifth family of arguments is a conceptual tool that has been used by scholars who sit on either side of my division.

Merit goods are associated with a negation of consumer sovereignty. Unsurprisingly, just as the concept of merit good is ambiguous, so is that of consumer sovereignty. The latter concept was popularized by the economist William Hutt in 1936. He defined the consumer as "sovereign when, in his role of citizen, he has not delegated to political institutions for authoritarian use the power which he can exercise socially through his power to demand (or to refrain from demanding)" (Hutt 1936, 257). Consumer sovereignty appealed to Hutt, both for economic arguments of efficiency, and because it constituted a defense of freedom for its own sake. In a broader intellectual perspective, the concept is an adaptation of individual sovereignty, a key idea in classical liberalism.

In a reply to criticisms of his concept, Hutt $(1940,66)$ reformulated it into a general principle of economics, as the science came to be defined by Robbins (1932). For Hutt, consumer sovereignty embodied "the controlling power exercised by free individuals, in choosing between ends, over the custodians of the community's resources, when the 
resources by which those ends can be served are scarce." In the New welfare economics, it came to be associated with the idea that only the preferences of rational individuals - as they outwardly express them - ought to count in evaluating social welfare. By the 1950s, another semantic layer could be added in the American context. The 'consumer is king' became the slogan for the mass consumption society. As the political context evolved, upholding consumer sovereignty came to stand for a defense of western democratic liberal values, in contrast to the so-called democratic regimes of the East (Amadae 2003, 4). It is used for instance by Arrow $(1951,30)$ to label two of his reasonable conditions for a democratic social choice. ${ }^{3}$ In this paper, I will define consumer sovereignty as combining two dimensions: First, (A) the assumption that individuals make rational choices, that they are sovereign over their choices and know what is good for them; ${ }^{4}$ second, (B) the principle that only, but all, individual preferences (or choices) ought to count in evaluating social welfare. ${ }^{5}$ The latter principle entertains a very close relationship with Pareto optimality. It

\footnotetext{
${ }^{3}$ Namely, Condition 2: 'Positive association of social and individual values' and Condition 4: 'non-imposition' of the SWF.
}

${ }^{4}$ As early as 1934, Hutt assumed that the validity of the competitive equilibrium rested on the assumption that consumers were rational. In the discussion on merit goods, the sovereign individual is conceived in welfarist and noncomparable utility terms, to use the expressions of Sen (1979).

${ }^{5}$ Note that the first dimension can be interpreted as positive, but the second one is resolutely normative. Desreumaux (2013) convincingly argues that consumer sovereignty is the central normative principle of (paretian) neoclassical economics. McLure $(1990,179)$ gives a definition of consumer sovereignty very close to the one I use. 
entails that only Pareto-improving policies are favorable. Otherwise, it would mean that some preferences are not respected in the social choice.

In relation to my typology of the literature, in the first category (section 1), the attempts to justify merit goods do so by rejecting or modifying (A) - the first dimension of consumer sovereignty; in the second category (section 2), the works reject (B) - the second part of the definition.

\section{THE MAINSTREAM APPROACH TO JUSTIFYING MERIT GOODS}

Most of the papers that try to justify the concept of merit wants and more generally the provision of merit goods have done so without questioning the central normative precept of welfare economics, namely that only (and all) individual preferences ought to count in matters of social welfare. What I call the mainstream approach encompasses diverse attempts to qualify the actual sovereignty of consumers over some of their choices. These discussions have their root in cursory comments made by Musgrave himself when he coined the concept. First, he tried to minimize the extent of the phenomena by noting that apparent merit wants might turn out to be social wants (collective wants), or at least mixed cases (Musgrave 1959, 13, 89). Then, he observed that "the basic doctrine of consumer sovereignty, finally, rests on the assumption of complete market knowledge and rational appraisal." Yet, who could contest that the modern consumer is subjected to aggressive advertising, "screaming at him through the media of mass communication and designed to 
sway his choice rather than to give complete information"?6 To Musgrave, this was "a source of distortion in the preferences structure that needs to be counteracted" (ibid., 14).

During the 1960s, the concept of public good - or social good as Musgrave calls it progressively acquired its standard definition as non-rival and non-excludable (DesmaraisTremblay 2015b). Yet, for most of the decade, not much had been written on merit wants. The Australian economist John G. Head (1932-2010) was the first to launch a discussion on the status of merit wants within the new normative theory of public finance. He set out hoping to bring the concept into the familiar framework of Pigouvian or Keynesian theories of public policy. Head (1966) wrote his first paper on the topic in 1965 while he was visiting Musgrave at Princeton University (Head 2009). He identified three underlying issues in merit wants: (i) preference distortion problems caused by uncertainty and irrationality; (ii) distributional problems inherent in Musgrave's conceptual separation of allocation and distribution; and (iii) public goods (or social wants) problems. In his frontal attack on the concept, McLure (1968) rejected Head's interpretation, which would have made the concept more acceptable to economists. He pushed the interpretation into a dilemma: the concept was either redundant - externalities would suffice - or unacceptable - it entailed a violation of individual preferences, which is what McLure thought Musgrave had in mind. The next year, Head (1969) replied to McLure's attack and tried to refocus his argument. He argued that "[t]he central characteristic of a merit good is that many

${ }^{6}$ Galbraith's (1958) essay had just been published. Musgrave did not refer to it, but the rise of the mass consumption society and its side effects must have been an obvious phenomenon to keen observers by the end of the decade. 
individuals are unable to evaluate the benefits correctly. The problem is therefore one of imperfect knowledge, broadly interpreted" (Head 1969, 214). Under this problem, he discerned two causes of incorrect preferences: ignorance and irrationality.

Meanwhile, in an important paper on public wants presented in 1966, Musgrave made brief remarks on merit wants. More than ever, the concept appeared as an inconvenient residual in his theory of public allocation. Musgrave repeated his 1959 argument: Important cases such as education combine elements of merit and social goods. Their overdetermination thus reduces the necessity to clarify the merit nature. Moreover, since "the advantages of education are more evident to the informed than the uninformed" (Musgrave 1959, 13), compulsory education could be justified as a temporary learning process (Musgrave 1969a, 143). Although he acknowledged that "reconciliation must not be carried too far," Musgrave presented "psychic externalities" as a way to justify merit wants of the in-kind redistribution type. ${ }^{7}$ Those externalities - different from the physical ones are defined as interdependence between the individual utility functions (Culyer 1971; Folkers 1974). This conceptualization of merit wants was first suggested by Tiebout and Houston (1962) in a paper that presented a rationalized description of the plurality of government function at the metropolitan level. ${ }^{8}$ The idea is simply that individuals might

${ }^{7}$ In fact, as new individualistic models of redistribution appeared (Hochman and Rodgers 1969; Pauly 1970), Musgrave (1970) stressed that a sizable part of the redistribution of wealth and income could not be justified in such Pareto-optimal ways.

${ }^{8}$ Charles M. Tiebout was a student of Musgrave's at the University of Michigan in the 1950s (Musgrave 1999, 158). 
voluntarily support in-kind redistribution if they derive utility from the consumption of some specific goods by others. Thus, at the end of the 1960s, the table was set for a discussion of merit goods in terms that could potentially reconcile them with the New welfare economics - namely, uncertainty, information asymmetry, and other circumscribed cases of distorted preferences. Indeed, many papers followed this lead, most of them published in the German journal Finanzarchiv - Public Finance Analysis in which Musgrave (1957), Head (1966, 1969) and McLure (1968) had made their seminal contributions to the debate. For instance, Auld and Bing (1971) maintained that merit goods could be conceived as relevant information about the characteristics of goods that markets do not provide to the customers and that should therefore be provided by the government. ${ }^{9}$ Convinced of the importance of staying in line with the individualistic perspective, Mackscheidt (1974) argued that individuals, in a pragmatic move, might temporarily delegate their power of choice to their political representatives when information is more costly to obtain privately than through public authorities.

Another modeling approach to merit goods as correcting for imperfect information was provided by Sandmo (1983). Assuming von Neumann-Morgenstern utility functions, he suggested that social welfare might be maximized using the social planners' probability distribution, rather than the less informed distributions of individual agents. Sandmo argued that respecting individual tastes (over state-contingent commodities) was the essence of consumer sovereignty. His attempt to find an individualistic basis for merit

${ }^{9}$ Their analysis suffers from serious problems that have been pointed out by Ballentine (1972) and Braulke (1972). 
goods intervention fitted with the optimal taxation literature which flourished in public economics in the 1980 s.

The positivistic and behavioristic turn of welfare economics in the first half of the twentieth century, which had economists shying away from interpersonal comparisons, created tensions within welfare economics (Cooter and Rappoport 1984). Economists came to realize that they could not draw many meaningful policy conclusions on those bases and thus many voices later emerged to criticize the thinness of the welfarist perspective. From a retrospective point of view, both the assumption of interdependent utility functions and that of distorted preferences can be seen as attempts to open up, or broaden, the conception of the individual in economics. The interdependence, or psychic externality, is a way to account for the fact that preferences are endogenous and that individuals have other-regarding behavior, quite different from the homo œeconomicus straw man. For instance, Sen's (1977) early revival of the concept of sympathy was a step in that direction. Blatant cases of deviation from the standard rationality, regarding time consistency for instance, also called for a thicker individual. One way to achieve this is to reject the revealed preference conception and assume some degree of reflexivity on the part of individuals. As early as the 1950s, Harsanyi (1955) had remarked that irrationality called for a qualification of consumer sovereignty. Moreover, he proposed to distinguish between the individual's subjective preferences and her ethical preferences, which led Sen (1977) to argue that the moral judgments made by individuals reflected a meta-ranking (a ranking of the different preference ranking of actions). In a similar vein, Basu (1976) asserted that a distinction between actual choices and retrospective choices could justify merit goods such as compulsory education. He identified three causes of discrepancy: (i) because the quality 
of the good might only be revealed through experience; (ii) because individuals discount time; (iii) and because their tastes might change over time. Basu maintained that Pareto optimality should be assessed on the more reflexive "retrospective choices."10

Brennan and Lomasky (1983) present a convincing case for taking into account the effect of the institutional setting on the way in which individuals make choices. They argued that individuals choose according to a different set of preferences in a political context called $p$-preferences - than when buying commodities at the market following their $m$ preferences. The political setting might lead individuals to vote for the provision of merit goods over and above their willingness to pay in the market for the same goods when they follow their $m$-preferences. ${ }^{11}$ Likewise, Cooter and Gordley (1995) develop a model to explain merit goods based on akrasia, in which majority voting reveals collectively more considerate judgments, because of the averaging effect, than from the impulsive acts of isolated individuals. More recently, Mann (2006) has synthesized and expanded on those arguments, basing his case for Pareto-improving provision of some merit goods on (i) better information on the part of the government, (ii) the government's capacity to help individuals mediate between market preferences and more reflexive ones, and (iii) the government's responsibility to internalize psychological externalities.

With the resurgence of behavioral economics in the late 1970s, new empirical evidence emerged to challenge the assumptions of standard economic rationality. While

\footnotetext{
${ }^{10}$ For a similar position, see Burrows $(1977,29)$.

${ }^{11}$ Similar ideas are also discussed by Head (1988).
} 
spreading to subfields such as public economics, it recently gave new life to the irrationality argument for merit goods. Sunstein and Thaler (2003) claim to have squared the circle of liberalism by directly influencing the individual's choice setting, while at the same time preserving their freedom. They argue that some form of paternalism is inevitable, but that it needs not be coercive (Thaler and Sunstein 2003). This led D'amico (2009) and Mann and Gairing (2012) to argue that this libertarian paternalism, based on new behavioral economics, could potentially reconcile merit goods with mainstream economics. ${ }^{12}$ In a recent book, Alistair Munro (2009) brings the results of behavioral economics into resonance with public economics, in particular through the concept of merit wants, for which he provides a new formal definition. He defines individuals as merit worthy if they are not strongly rational, either because they are not even weakly rational, or because their preference ordering is not reflected in the social welfare function. An individual who is not weakly rational is bounded rational, which means either that she does not have a preference ordering over all social states, or that her preferences are frame dependent. In other words, the revealed preferences might change depending on the context of the choice situation. ${ }^{13}$ Historically, the revival of behavioral criticism emerged out of the breaking up of the Cold War rationality paradigm of research in the social sciences. Yet, ironically, it is

\footnotetext{
12 This lead is also followed in the surveys of Clément et al. (2009), Sturn (2015), and Kirchgässner (2015).

${ }^{13}$ For the formal definitions, see Munro (2009, 6 ff.). Following this definition, Munro provides in the seventh chapter of his book a review of the optimal taxation models of merit goods, especially the recent ones such as Racionero (2000) who follows in the footsteps of Sandmo (1983) by focusing on information provision.
} 
also an offspring of this very economical perspective on social life, and is gradually becoming part of mainstream economics (Erickson et al. 2013; Davis 2006, 2008).

In sum, the subjective and behavioral notion of welfare implicit in the New welfare economics posed methodological problems to economists such as Musgrave, who wanted to study the allocative and distributional functions of the state in a comprehensive way. Economists who addressed this problem tried to qualify the standard conception of consumer sovereignty by conceding specific cases in which individuals were not the best judges of their welfare, without rejecting altogether the stronger normative precept that preferences - broadly understood - ought to be the norm for social welfare. In retrospect, the mainstream approach to merit goods is characterized by negative reasons for government interventions. This is a common feature of the market failure approach, which conceives the market as the baseline allocation mechanism, unless a problem is encountered. Thus, irrationality, psychic externalities, and information asymmetries can be added to the list of causes of failure, which already contained (physical) externalities, impossibility of exclusion, non-rivalry in consumption, decreasing marginal cost, or more generally problems of appropriation. Furthermore, this negative approach is also a feature of the implicit representation of the person: the rational sovereign individual is now seen as subject to different biases and limited cognitive capabilities.

\section{A BIGGER CHALLENGE TO WELFARE ECONOMICS}

In this section, I reconstruct my second category of the literature on merit goods, which departs more forcefully from welfare economics. Contrary to the previous section, the 
arguments put forward in the texts in this category are positive in the sense that they do not rely on the market failure approach, but rather try to define what could be an "alternative norm" to consumer sovereignty (Musgrave 1987) for rationalizing and justifying some public expenditures. Two related dimensions of the problem of consumer sovereignty are missing from the market-failure explanation: the political and the ethical. Again, Musgrave hinted at those necessary aspects of a comprehensive and realistic theory in his early discussion. He expressed a "mild moralistic position" (Ver Eecke 2007, 6), without providing a philosophical argument: "A position of extreme individualism could demand that all merit wants be disallowed, but this is not a sensible view" (Musgrave 1959, 13). ${ }^{14}$ As for the political dimension, he asserted the importance of leadership in the institutional context of a democratic community. In his second paper on the topic, Head $(1969,224)$ observed that "Musgrave's approach has some flavor of both the ethical and the political approaches." He also acknowledged that the concept of merit goods requires an extension of the welfare framework beyond the Pareto approach (ibid., 225), but he did not follow this suggestion in his own justification attempts. ${ }^{15}$

In inventing the concept of merit wants, Musgrave may have been trying to find a compromise in favor of Gerhard Colm's long-standing opposition to the individual preference approach to public expenditures (Desmarais-Tremblay 2015a). According to Colm, this approach "overlook[s] the essentially political character of the budget process

\footnotetext{
${ }^{14}$ In his review of the Theory of Public Finance, Wiseman $(1960,266)$ noted that Musgrave failed to directly address the problems of political philosophy he raised.

15 The political dimension is also conceptualized by Pulsipher (1971); Folkers (1974); Mackscheidt (1974); Brennan and Lomasky (1983) and Rüffer (2007).
} 
and the essentially social nature of its objective" (Musgrave 1959, 87). Consequently, Colm regretted that Musgrave devoted so much attention to the individual benefit theory, but only "much briefer (and rather vague)" discussion to the "principles for determining" merit wants (Colm 1960a, 119). In Colm's view, the public interest was a more "comprehensive and operational" guiding principle for the conduct of the different actors that compose the political process (leaders, bureaucrats, pressure groups, public opinion, voters, etc.) (Colm 1960a, 1960b, 1965). Moreover, he claimed that the public interest also "serves as a criterion for the satisfaction of 'merit wants' " (Colm 1960a, 119).

The restrictions imposed by the New welfare economics on questions of distribution turned out to be too severe for a broad conceptualization of the role of the state in society (Backhouse and Nishizawa 2010a). Trained as a philosopher, John Rawls developed a serious interest in economics in the 1950s (Hawi 2011). His Theory of Justice (1971) set in motion a discussion between philosophers and economists which allowed the latter to reflect on the normative basis of their science. Rawls accepted the challenge that economists were helpless to solve: how to build a substantial and consensual (or convincing) ethical view from sound premises that respected individual autonomy and could face the socioeconomic problems of postwar America. In his theory of justice as fairness, once the basic structure of society guarantees freedom to everyone, the institutions should be organized so as to maximize the welfare of the least-well-off citizen. To do so, certain interpersonal comparisons of welfare have to be accepted. Rawls's objective basis of comparison is an index of primary goods, which include basic liberties, freedoms, opportunities, income and wealth, and social bases of self-respect (Rawls 1982, 1971, 90ff). Rawls's inference that citizens in a just society might reasonably expect it to 
provide them with a basic level of such goods rests on an ethical thought experiment. According to Musgrave, the disinterested position behind the veil of ignorance influences the individual's sovereignty to choose, leading her to more reasonable judgments on how the primary distribution should be made. Musgrave (1987) only hinted at a link between Rawls's primary goods and his concept of merit goods. Recently, Ege and Igersheim (2010) have convincingly argued that some merit goods such as education and healthcare services should be included in the fourth type of primary goods considered by Rawls: income and wealth. Indeed, Rawls $(2001,172)$ later remarked that the citizens' reasonable expectations of government services included many "personal goods and services" that could be labeled as merit goods.

Just before Rawls published his Theory, James Tobin (1970) delivered a lecture in which he called for limiting inequalities through "specific egalitarianism." Tobin argued that every citizen should be assured a minimum quantity of certain scarce goods - such as basic foods in wartime, medical care, basic shelter. Musgrave (1987) referred to this view as "categorical equity" and argued that it constituted an idea of redistribution akin to merit goods. Although Tobin never used (in print) the concept of categorical equity, nor that of merit goods, Musgrave considered that Tobin's plea "renders prestigious support to the merit good approach."16

A fully fledged ethical discussion can bring more radical criticism of welfarism. At a conference held in Australia in 1986 on the topics of rationality, individualism, and public

16 The quotation is from a letter from Musgrave to W. Ver Eecke, October 12, 2003. Richard A. Musgrave Papers, Box 6, “Correspondence," Princeton University Library. 
policy, ${ }^{17}$ the philosopher Charles Taylor presented a paper in which he attacked the atomistic and individualistic conception of the good in welfarism. He argued that there are irreducibly social goods that lose their substance when conceptualized in individualistic terms. For Taylor (1990), individual agency only exists against a background of available meanings and other practices which are located in a shared culture. Language is such an irreducibly social good. Another instance is friendship, the goodness of which must be "the object of shared understanding," or else it would not be friendship. More generally, Taylor argues that welfarism is a screen that hides the complexity of political and moral aspirations. For example, the aspiration to participatory self-rule is a very strong element of the civic humanist tradition and is still part of the modern political identity of citizens in many countries (Sandel 1996). Yet, it is badly understood by the individualistic liberal tradition of which welfarism and utilitarianism are part. Taylor also claims that our moral sense admits qualitative contrasts between orders of goods which cannot be captured by a utility function (Taylor 1982). Human beings strive for excellence ${ }^{18}$ in certain activities of their life, and these aspirations are not well captured by a flat preference-satisfaction

17 The concept of merit good was explicitly discussed by many participants and Musgrave's (1987) and Head's (1988) retrospective surveys of the concept were rewritten after the conference, according to the organizers, Brennan and Walsh (1990).

${ }^{18}$ Cooter and Gordley (1995) also develop their merit good model on Aristotelian arguments about excellence. 
conceptualization. ${ }^{19}$ One example given by Taylor illustrates the conception of merit goods as irreducibly social goods that is defended by Grinberg and Rubinstein (2005). He explains how the majority French-speaking community in Québec take political actions to preserve their language and their culture within the larger English-speaking population of North America. Language is seen as a common good which led the democratic assembly to enshrine collective rights in a charter that take precedence over the choices some individuals might want to make (Taylor 1990, 58). Without necessarily endorsing these political aspirations, Taylor proposes that, if they are genuinely important for the members of one community, then the theory has to be able to make sense of them without completely deforming its reality. In this sense, merit good policies are a symptomatic manifestation of the narrowness of welfarism, when the latter attempts to rationalize the whole of social life.

Later in his life, reflecting on his German roots, Musgrave leaned in that direction: "Admittedly difficult to define and dangerous to entertain, communal concerns have been part of the scene from Plato on, and my concept of merit goods (applicable to private and social goods alike) was to provide a limited opening for their role" (Musgrave 1997, 30). A related, but even more foreign, notion to most economists is that of the common good as understood either in the Thomist or in the Hegelian tradition. When brought into resonance with social sciences, Mastromatteo and Solari $(2014,93)$ define the common good as "an inter-subjective evaluation concerning the realization of the processes needed to fulfill the

${ }^{19}$ That being said, following Frankfurt (1971), the idea of higher-order goods has already been used by economists who modeled it using ranking of preferences, as was mentioned in the previous section. 
needs of the community. It concerns 'an order of society' that is not reducible to individual needs and desires and is political in nature." This allows them to define merit goods as "instruments used by the government to help achieve synergies with the action of members of the community towards the pursuit of that end [the common good]" (ibid., 96). In this sense, the common good is an intrinsically vague notion which cannot be produced like a commodity, but is rather a guiding force for the action of all the social actors, not unlike Colm's idea of the public interest. In their understanding of merit goods, Mastromatteo and Solari (2014) have been influenced by the writing of the philosopher Wilfried Ver Eecke.

Ver Eecke has devoted considerable attention to the concept of merit goods. In addition to the large collection of fragments of Musgrave's writing and secondary sources on merit goods that he collected in his Anthology (2007), he also proposed his own extended interpretation of the concept in a series of contributions. For Ver Eecke, the concept of merit goods was a Trojan horse in economics which led to an "unfinished ethical revolution." A full acceptance of the concept would involve a "paradigm shift" from an "individualistic view of economics to a socio-economic viewpoint" (Ver Eecke 1998, 134). In this regard, the provision of merit goods involves government activities that will "neither respect the Pareto principle nor the consumer sovereignty principle" (ibid., 139). Ver Eecke identifies merit goods using a transcendental argument. This type of argument, famously devised by Kant, calls for identifying the logical possibility conditions for something to be: "We shall call merit goods those goods which are the conditions for the possibility of something that is desired by the consumers, even and especially if these merit goods or 
services themselves are not preferred by consumers" (ibid.). ${ }^{20}$ The philosopher then takes the following as a premise: "The first thing that Western citizens as economic actors wish is a free market" (ibid., 140). Then, drawing from Adam Smith's and Henry C. Simons's writing, Ver Eecke deduces a list of necessary governmental interventions to secure a free market. The list includes the traditional night-watchman state functions and further neoliberal duties such as enforcement of competition against monopolies, but also education as a means to improve "the rationality of the consumers" (ibid., 143). In a recent elaboration of his argument, Ver Eecke (2013, Chapter 4) produces a list of eleven categories of merit goods: limited property rights, institutions to promote efficiency, business cycle stabilization, education, a limited safety net, public health measures, a wellfunctioning social contract, transparency and prevention of corruption, strategic planning and industrial policy, environmental protection, and protection of cultural heritage.

There are at least three problems with Ver Eecke's argument. First, his premise is far from consensual. Even if we accept a flexible definition of the concept of free market, ${ }^{21}$ it is

20 This definition would align merit goods with the concept of intermediate goods (see Colm $1965,215)$. Musgrave (1969b) already used the concept of intermediate social goods to describe these cases, something that Ver Eecke does not mention.

${ }^{21}$ One way to interpret Ver Eecke's claim that economic actors desire a free market is through his reading of Hegel's Philosophy of Rights. For Hegel, the market, or civil society, is an ethical institution that emerged with the growth of commercial society in the modern age. The identity of the economic agent is concomitant with the emergence of a free economic sphere. So the market can be understood as promoting individual freedom in the modern world. It realizes the individual's subjectivity (Ver Eecke 2008, Chapter 3). Yet, it is 
not obvious that citizens in western countries are all striving for that institution, let alone the fact that as an institution it is only an intermediate good in itself. In this regard, the Rawlsian approach presented above, which also conceives of merit goods as instrumental stepping stones, is more generally applicable because it does not presuppose any specific conception of the good. Second, even if one accepts his premise, Ver Eecke's types of merit goods are not pure deductions in the Kantian sense that space and time are necessary for making sense of empirical reality. Nor can they be deduced from the practical categorical imperative. They are more of the hypothetical imperative type, because they depend on empirical knowledge. That such-and-such an institution is favorable to market efficiency has been a matter of debate among economists for centuries.

Third, Ver Eecke's approach leads him to argue that national defense is a merit good, along with other previously labeled public goods. Yet, he forcefully defends the conceptual separation between public goods and merit goods, arguing that they are both ideal concepts (Ver Eecke 1999, 2003). In view of the conceptual overlap on particular tokens such as national defense, it is not clear that such an extension of the concept of merit goods helps to clarify the public policy debate, let alone convince economists to use the concept. Overall, there is a tension between Ver Eecke's wish to broaden the concept and his intention to limit its range (Ver Eecke 1998, 139). He sees a limitation inasmuch as government needs reasons or arguments to take over some responsibilities for guaranteeing the efficiency of the market. Still, this requirement of providing public reasons for state action is also a

not self-sufficient in the sense that the state, as a higher ethical realm, must solve some of the contradictions generated by the market (Hegel 1821). 
common theme of many theories of deliberative democracy. Thus, it is not clear that the concept of merit goods really brings something new for that purpose. Nonetheless, Ver Eecke's writing provides a heuristic approach to discussing governmental duties without the straightjacket of market failure. His aim is not to prescribe specific policies, but mainly to open the debate (Ver Eecke 2013, 57, 79).

The ethical (and political) interpretative strand of the concept that I reconstructed in this section started later than in the first mainstream strand discussed in the previous section. This lag, just as with Musgrave's apparent lack of sufficient arguments to justify the concept at the end of the 1950s, reflects the absence of a suitable ethical theory for economists to rely on. Sen's and Rawls's theories of justice are appealing to economists because they allow for a rational discussion of normative issues, something that was not available at the time Musgrave coined the concept. The ordinalist revolution successfully converted economists to the idea that normative issues were non-scientific and welfare was only a subjective dimension that could be measured through the revelation of choices (Cooter and Rappoport 1984). The conversion succeeded, because the two moral theories in vogue in English-speaking countries in the first half of the twentieth century were G. E. Moore's intuitionism and the emotivist theory of A. J. Ayer, which had strong roots in the sensualist tradition (Davis 1990). ${ }^{22}$ Ironically, Moore's intuitionism served as a straw man

22 Backhouse and Nishizawa (2010b) reveal the plurality of views on welfare in Britain in the 1920s. Yet, by the 1930s, the positivist aspirations of economists had considerably reduced the range of acceptable positions, in particular among the younger generation of LSE economists. 
of cognitive ethics which justified the rejection of cognitivist approaches altogether. ${ }^{23}$ Thus, when Robbins condemns normative judgments as non-scientific, it is because he takes morality as mere feelings, which cannot be the object of a rational discussion:

In the rough-and-tumble of political struggle, differences of opinion may arise either as a result of differences about ends or as a result of differences about the means of attaining ends. Now, as regards the first type of difference, neither Economics nor any other science can provide any solvent. If we disagree about ends, it is a case of thy blood or mine - or live and let live, according to the importance of the difference, or the relative strength of our opponents. But if we disagree about means, then scientific analysis can often help us to resolve our differences. If we disagree about the morality of the taking of interest (and we understand what we are talking about), then there is no room for argument (Robbins 1932, 134).

Twenty years later, Friedman drove the point further when he argued that economics should focus on positive issues because normative ones can only lead to emotional disputes:

I venture the judgment, however, that currently in the Western world, and especially in the United States, differences about economic policy among disinterested citizens derive predominantly from different predictions about the economic consequences of taking action-differences that in principle can be eliminated by the progress of positive economics - rather than from fundamental differences in basic values, differences about which men can ultimately only fight (Friedman 1953, 5).

\footnotetext{
23 Yet, as Habermas (1990, $50 \mathrm{ff}$ ) observes, moral theory does not need to be intuitionist or emotivist. A similar point is made by Nussbaum $(2000,127)$ : She explains Harsanyi's hesitation to engage with a normative theory of justice on the grounds that he was convinced that the two moral theories available were G. E. Moore's theory of mental states and hedonism.
} 
This might explain why, in 1959, Musgrave could only assert that rejecting all merit wants "is not a sensible view" without providing convincing normative arguments to back his claim. In other words, there was no ethical theory available to justify his merit wants.

\section{FROM A SOCIAL VALUE SCALE TO NON-INDIVIDUALISTIC SOCIAL}

\section{WELFARE FUNCTIONS}

In this section, I discuss some attempts at representing merit goods in a formal manner with a non-individualistic social welfare function. Even if it does not aim at a reconciliation, this mathematical representation is general enough to capture both strands of justification previously discussed. These formalization attempts date back to the early 1970s. Moreover, I claim that this representation is actually very much in line with how Musgrave conceptualized the state in his unpublished $\mathrm{PhD}$ dissertation, at a time when he was not constrained by the methodological rules of New welfare economics.

In his dissertation defended at Harvard in 1937, Musgrave brings together the expenditure and the taxation sides of public finance in a rational theory of the government budget. He wants to assess the net effect of the revenue-expenditure process on the national welfare. On the question of the subject of his rational model, Musgrave rejects both the Italian subjectivist assumption and the organic view defended by some German scholars. ${ }^{24} \mathrm{He}$ argues that social wants are neither felt directly by the individuals, nor are

\footnotetext{
${ }^{24}$ Mazzola (1890) and De Viti de Marco (1934) are representatives of the Italian tradition. Ritschl (1931) is a twentieth-century representative of the older German holistic view.
} 
they felt by the community as a whole. Musgrave rather adopts the German public household approach. Accordingly, a more realistic subject for his model is the budget planner. When trying to assess the benefits of public services, Musgrave runs into trouble. He struggles to attribute benefits to individuals when some needs can only be satisfied by indivisible goods that benefit everyone equally. Musgrave names them social wants proper. Besides, he assumes the existence of individual needs that are normally satisfied by goods allocated by the market. Yet, the Public Economy (or the state), thanks to its coercive power, can also decide to satisfy individual wants (Musgrave 1937, 335). Next arises the question of how to compare the benefits of services that satisfy individual wants and those that satisfy social wants proper. Musgrave claims that the state planner can homogenize the heterogeneous collection of needs by reducing them to a common denominator, social importance:

The comparison is rendered possible by reducing both types of wants to a common denominator, thus rendering the aggregate body of wants homogeneous. The government, if deciding to satisfy "individual wants" looks at the latter from the point of view of social necessity, i.e., they are satisfied qua social' - not qua individual' wants. While, therefore, from the point of view of the individual household, the total system of wants appears non-homogeneous (consisting of individual and social wants), from the point of view of Public Economy the total system of wants is homogeneous (consisting of social wants proper and socially interpreted individual wants) (Musgrave 1937, 336).

Thus, the public economist can assume that a given schedule of social wants is available to him, just as he would assume a given set of preferences in consumer theory. This idea of a schedule of social want is a direct, unformalized, antecedent to Bergson's idea of Economic Welfare Function (1938) which will be reframed into Social Welfare Function (SWF) by Samuelson (1947), both Harvard colleagues of Musgrave's. After the war, Musgrave will abandon his phrase of a schedule of social wants in favor of SWF. 
Furthermore, we can see in the idea of socially interpreted individual wants a direct ancestor to the concept of merit wants. Yet, in his dissertation, this type of want does not pose a greater methodological problem than other social wants proper, because Musgrave takes the public household perspective and he does not attempt to relate the evaluation of social wants to individual demands. He does not question the suitability of an overarching point of view. For instance, he notes that there are cases of transfers in kind in which individuals undervalue some goods compared to their social value:

[There exists] a large number of public expenditure items, aiming the satisfaction of individual wants, but proceeding on the basis of social, rather than individual, evaluation of such wants. Instead of housing, a free supply of educational, medical or sanitary services could have been chosen as examples. Not only may in certain instances the individual evaluation of such services be below the social one, but it may actually be zero or negative. [...] The sociological process in back of the formulation of social value scales is far more intricate than that of the simple arithmetical addition of items of individual evaluation (Musgrave 1937, 348-9).

Hence, by taking the Old welfare position of a social value not reducible to individual evaluations, Musgrave could assume that the state was satisfying both social wants proper and socially interpreted individual wants (later merit wants). ${ }^{25}$ The social planner was assumed to be taking decisions on the basis of the scale of social importance that comprises both types of need.

25 The 'Old' welfare character of Musgrave's dissertation follows from his public household point of view and his acceptance of interpersonal comparisons as a "workable assumption." Following Pigou (1932), he argues: "The capacity to enjoy benefits is after all but part of the general nature of 'man.' It being the generally accepted procedure to define certain general characteristics of men, there is no reason why no typical degree of intensity for the enjoyment of benefits could be assumed" (Musgrave 1937, 274). 
Bergson and Samuelson's SWF rendered explicit the social value judgments made in welfare economics. To respect the common assumptions at the time, Samuelson argued that economists would agree on SWF that were monotonously increasing functions of the individual utilities. Musgrave assumed throughout his life that decisions on public goods in a democratic society had to reflect, in some way or another, the choices of the citizens. Yet, for most welfare economists, Arrow's (1951) impossibility theorem was inconvenient, because it meant that the SWF could not represent a collective choice aggregated from individual preferences. To avoid the problem, many welfare economists retracted their ambition and reinterpreted the SWF as representing the view of a single individual (Desmarais-Tremblay 2014, 279). Still, for many, the SWF was a tool to represent society's value judgments, including cases in which they might differ from those of some of its members. At the very least, it was acknowledged that the standard utility representation of individuals could not account for many goods provided by the state.

Elisha A. Pazner (1972) addressed this problem in a paper based on the first chapter of his dissertation written at Harvard under the supervision of Musgrave. He defined merit wants as cases in which society, represented by a SWF, would "impose [its] choice." In line with what I called the mainstream approach, he argued that the only acceptable rationale for non-individualistic imposed choice was based on the premise of imperfect information (Pazner 1972, 461). Yet, like many others modeling work in that vein, he avoided the question of how these societal judgments were related to individuals. As Roskamp (1975) put it: "If we introduce in the following analysis social preferences it should be understood that these are based on individual preferences, though we do not know, in what way precisely, individual preferences generate social preferences, given the present state of our 
science." Pazner uses the following notation: For individual $h(h=1, \ldots, H)$, the amount of private good $j(j=1, \ldots, n)$ she consumes is $x_{j}^{h}$. She derives utility $U^{h}$ from her consumption vector $x^{h}=\left(x_{1}^{h}, \ldots, x_{n}^{h}\right)$. Pazner then defines the general formulation of the SWF to account for merit goods as:

$$
W=W\left(U^{1}, \ldots, U^{H} ; x_{1}^{1}, \ldots, x_{j}^{h}, \ldots, x_{n}^{H}\right)
$$

with $W$ increasing in each of its $U^{h}$ arguments and $\frac{\partial W}{\partial x_{j}^{h}} \neq 0$ for at least one good - a merit good. W captures the idea that society values some goods over and above the value that individuals express in their utility function, which is why these goods enter as direct arguments in the SWF. In this general formulation, society can give weight to any specific good consumed by any individual. It provides a formal representation of the quantity of goods society might wish to distribute (allocate) to specific individuals (or groups of individuals) above what they would buy in the market. It thus combines the ideas of merit goods as redistribution in kind and of "social value judgments" (Rüffer 2007). In the rest of his paper, Pazner (1972) assumes that only the aggregate level of the merit goods enter the SWF, disregarding the information on their distribution. ${ }^{26}$ He then derives the necessary conditions for optimal allocation. The first-best solution is a set of commodity taxes for

${ }^{26}$ The SWF thus becomes $W=W\left(U^{1}, \ldots, U^{H} ; X_{1}, \ldots, X_{n}\right)$ where $X_{j}=\sum_{h} X_{j}^{h}$ 
demerit goods and subsidies for merit goods. ${ }^{27}$ The effect of this system of excise is that producers face different prices from consumers (Pazner 1972, 469). ${ }^{28}$

Pazner's merit goods are specific commodities. Yet, ever since Musgrave coined the concept, many have argued that they are social or public goods, or at least partially public goods. In his famous paper, Samuelson (1954) had derived the optimality conditions in the presence of collective goods for an individualistic social welfare function. The suggestion of incorporating collective or public goods directly in the SWF similarly to equation (1) was made by Johansen (1965). Although Pazner (1972) does not refer to Johansen, his book was widely known in public economics/public finance by the time he defended his dissertation. Johansen did not use the concept of merit goods, yet he justifies his suggestion using a familiar argument: "it may easily happen that the authorities of a country ascribe to public use of goods and services a value beyond that is expressed through individual preferences scales" (Johansen 1965, 128). Thus, in a world of two individuals, A and B, the social welfare function can take the form:

$$
W=W\left(U_{A}, U_{B}, G\right)
$$

where $G$ is the "collective want." This suggestion was followed by Folkers (1974), who derived the necessary conditions for optimal provision of private-merit and public-merit

${ }^{27}$ Respectively defined as $\frac{\partial W}{\partial X_{j}}<0$ and $\frac{\partial W}{\partial X_{j}}>0$.

${ }^{28}$ In terms of the general formulation where merit goods are indexed to individuals, it would call for individualistic prices. 
goods. ${ }^{29}$ A few years later, Baigent (1981) tried to overcome the "ad-hoc" definition of the non-individualistic welfare function comprising merit goods by proposing a model with individualistic foundations. He assumes that the set of commodities consumed by an individual $i$ can be separated into two subsets: those that have a merit value $x^{i}=$ $\left(x_{1}^{i}, \ldots, x_{m}^{i}\right)$ and those that do not $y^{i}=\left(y_{1}^{i}, \ldots, y_{n}^{i}\right)$. Furthermore, following Arrow (1951), he assumes that individuals have a ranking according to tastes and a ranking according to values, defined respectively as $T=T(x, y)$ and $V=V(x, y)$. Baigent asserts that social choice reflects individual values, as individual behavior is based on both tastes and values. ${ }^{30}$ He then shows that, for special cases of the behavior function, it is possible to represent the individual values as a function of the behavior and of the merit goods:

$$
V(x, y)=G(B(x, y), x)
$$

This individualistic value function exhibits the same form as the desired non-individualistic SWF. ${ }^{31}$ It can thus be aggregated into the desired SWF form, a step that is not realized by Baigent (1981) in his short paper. It means that non-individualistic functions might have an

${ }^{29}$ A similar model has been developed by Roskamp (1975) apparently without knowledge of the Pazner (1972) and Folkers (1974) papers. He uses a more cumbersome typology of private, merit, and public goods, and defines the SWF as a function of the individual utilities and of a set of society's preference functions for the merit goods (rather than just the goods directly entering as argument). Besley (1988), Walsh (1987), and Cooter and Gordley (1995) are among those who also used a similar non-individualistic function for conceptualizing merit goods.

${ }^{30}$ The behavior function can be expressed as $B(x, y)=B^{0}(T(x, y), V(x, y))$.

31 Provided that the individual utilities are represented by behavior functions. 
individualistic basis, but Baigent's proof does not provide a way of tracking back to see whether any specific SWF had such a basis or not (Munro 2009, 171). A political procedure has to be theorized in order to explain how merit considerations might arise in the collective choice process. The conceptualization of merit goods as direct arguments in a non-individualistic social welfare function allowed the concept to enter public economics. For example, it was recently used by Dasgupta $(2005,240)$ as an argument to show that contemporary (mainstream) economics can deal with different ethical foundations.

The non-individualistic SWF can also represent many views discussed in the first and second sections of this paper. Since it is blind with respect to the aggregation procedure, it is compatible with many moral and political theories. It is consistent with the idea that the citizens' moral sense might lead them to support policies which put more weight on specific goods, or to provide basic amounts of certain goods to citizens disadvantaged by the primary market allocation. Yet, it can also be used to represent the correction of individual choices because of frame-dependence, or lack of information. Finally, the merit dimension is applicable to technically collective and private goods as well.

In retrospect, the non-individualistic SWF formalizes Musgrave's early idea of a homogeneous social value scale, combining both social wants and socially interpreted individual wants. Both represent a social value judgment, or a social perspective that is not (necessarily) reducible to individual value judgments. However, Musgrave's social value scale was conceived for the Public Economy only. Contrary to a SWF, it was not meant to represent in a single expression the welfare of the whole National Economy. 
Still, is the non-individualistic SWF synthesizing all approaches to merit goods? I will mention four objections to this inference. First, if all policy-relevant considerations were included in the SWF, for instance everything that is required for human flourishing, then the simple formula might lose its usefulness. Second, the merit goods in the SWF might represent Rawls's primary goods, but, like most apocryphal use of Rawls by economists, it would not fully respect his Theory of Justice. Rawls's justice as fairness is a liberal Kantian theory that rejects the utilitarian conceptualization implicit in utility function representation, because it does not give absolute priority to the right over the good. Third, it seems that the non-individualistic SWF is unable to distinguish between goods that have an irreducible social nature and goods for which the social planner would like to proceed to direct allocation in kind. The formalism is flexible enough to be compatible with both interpretations, which also means that it fails to single out specific policy purposes. This is a common feature of many mathematical representations in economics. Translating concepts into formal definitions reduces ambiguity, but it can also hide the diversity of potential semantic interpretations. In a nutshell, fixing a formal representation for merit goods does not resolve the question of the legitimate interventions of the state, raised in the previous two sections.

\section{CONCLUSION}

For all its conceptual ambiguities and the fact that it was rejected by many economists, it is striking that the concept of merit wants has survived for 60 years. At least it has outlived its creator who passed away in 2007 (see Figure 2). The graph shows that occurrences of merit wants (and merit goods) are relatively more numerous than references to "Richard A. 
Musgrave" in the books digitalized by Google. The survival of the concept points to two conjectures on the history of welfare economics: First, we can tentatively suggest that the strict adherence to the consumer sovereignty principle was an interlude; and, second, we can infer that a 'social point of view' endures through time.

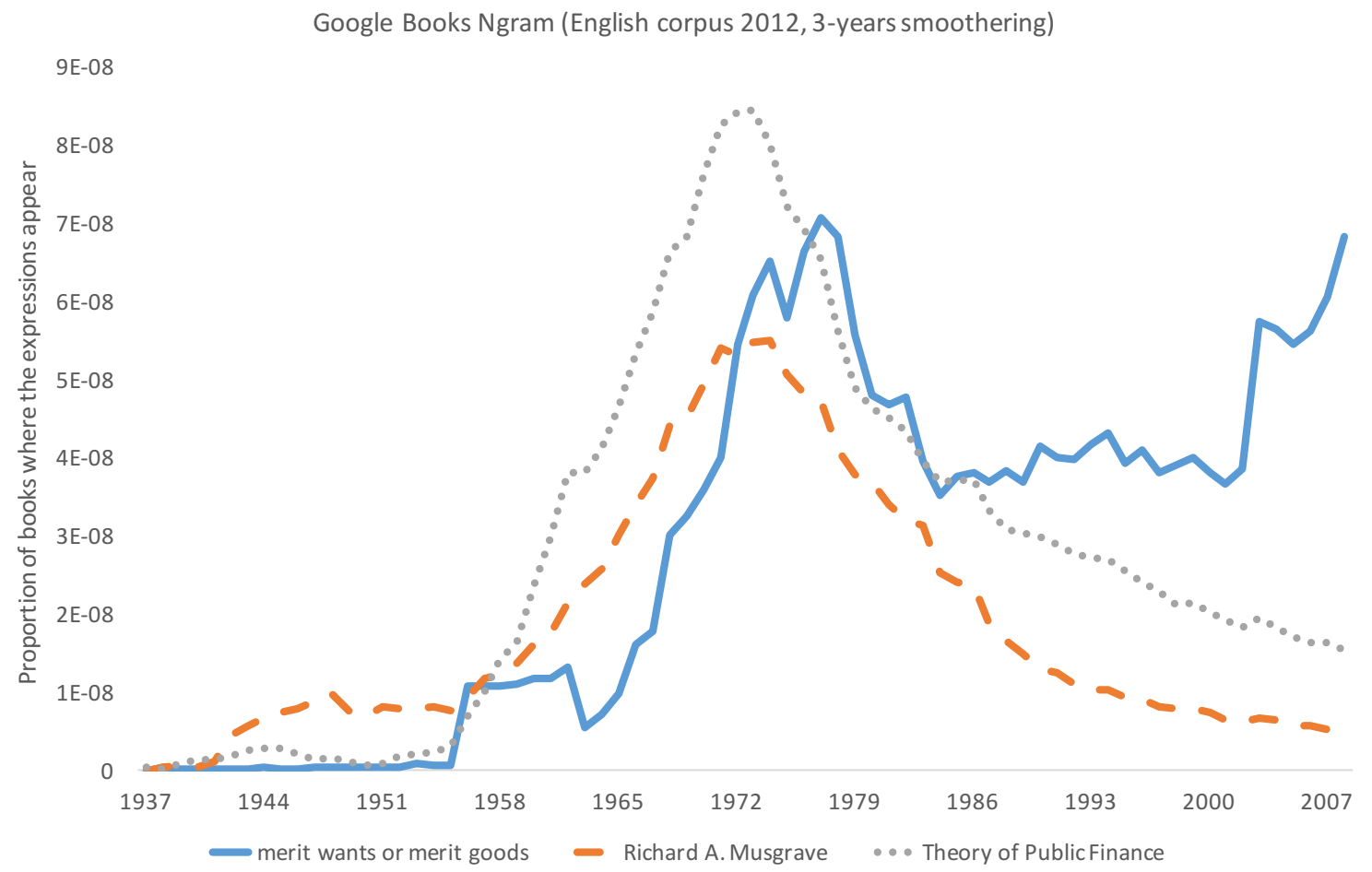

Figure 2: Ngram - The resilience of merit wants

It is now well acknowledged that the constraints imposed in the New welfare economics were too strong to make substantial policy recommendations (Sen 1979; Baujard 2015b, 2015a). The survival of the concept of merit wants further suggests that the strict application of the consumer sovereignty principle, and welfarism more generally, turned out to be a short interlude in the longer history of welfare economics. 
When the concept of merit wants was coined, economists did not have the theoretical tools to grasp it. Musgrave advised them to look elsewhere, not unlike in the old joke about the economist trying to find his keys under the lamppost because it is the only place where there is light: "The general problem of optimal distribution, or that of merit wants, presents much greater difficulties. Thus it is proper for the economist to concentrate on the problem of social wants. Moreover, the phenomenon of pure merit wants is not so general as it seems at first sight" (Musgrave 1959, 89). As long as economists focused on questions of efficiency, the new welfare economics could provide a sophisticated theoretical framework. Musgrave tried to move redistribution matters aside in a politically determined distribution branch of his Theory of Public Finance. The allocation branch could then take care of social goods in line with individual preferences, thereby adhering to consumer sovereignty. Yet, redistribution in kind showed up like an unwelcome guest at a party. With hindsight, Musgrave became proud of his inconvenient concept: "the skeleton has remained in my closet and I am pleased to remain responsible for it" (Musgrave 1983, 3). Addressing equity issues was important for Musgrave, who wanted to build a comprehensive and useful normative theory of the public sector. To do so, Musgrave had to violate certain rules by combining elements of Old and New welfare economics. This path was also followed in the field of public economics which grew out of public finance in the early 1970s (Mongin 2006). For instance, interpersonal comparisons of well-being were part of the Old welfare tradition (e.g., Sidgwick, Pigou), just as they are now part of most substantial approaches to justice (Dowding 2009). As Rawls put it in a lecture commenting on Cooter and Rappoport (1984): 
[T]here is nothing unusual in the use of primary goods as a basis of interpersonal comparisons. The underlying idea resembles that of material welfare; and indeed that of any other view that would base these comparisons on some normative conception of needs and requirements, or certain specified and protected interests. Thus, it resembles Scanlon's conception of urgency and Sen's conception of basic capabilities $[\ldots]^{32}$

In any case, welfare economics must posit a definition of social welfare. Musgrave coined the concept of merit wants to represent social judgments that are not easily reduced to individual valuations. One argumentative path has been to enrich the conception of the individual and that of the institutional setting in order to reestablish the individual welfare/social welfare link (section 1). A second path has been to reject the reduction and maintain socially non-reducible values (section 2). The non-individualistic SWF is a tool to represent various perspectives on this issue. By making explicit the social point of view, it permits a comparison with older conceptualizations of a social point of view, such as that taken by Musgrave in his dissertation before he coined the concept of merit goods (section 3). This narrative brings out the persistence of a social, national, or collective point of view in economics.

The necessity of a social point of view for economic theory is an open question. At least, it seems inevitable in political discussions and surely represents a challenge for economists, as Clark $(1936,44)$ acknowledged:

The search for standards of social value in the economic realm is a baffling task, yet far from an unprofitable one. We shall presumably never discover a definite yardstick of social value comparable to

32 John Rawls, "Philosophy 273 Primary goods and the concept of material welfare." October 17, 1984. Papers of John Rawls. Harvard University Archives. Box 37, Folder 14. 
the dollar yardstick of exchange values; but we may find standards by which those of the market may be revised, or in some instances replaced.

By embodying a social perspective, the concept of merit goods can serve as an intermediary to help make public policy debates more rational and transparent. Participants in a debate benefit from having different categories to disentangle the issues at stake; externalities and public goods might not be sufficient. The content of the debates certainly changes over time and space. In the United States after World War II, progressive economists pointed to the deficiency of decent housing and nourishing meals for some parts of the population. The current discussions on the role of government in higher education funding, on universal health insurance, or that of taxing unhealthy soft drinks might also benefit from a conceptualization in terms of merit goods.

\section{ACKNOWLEDGMENTS}

Earlier versions of this paper were presented at the Summer School in History of Science and Economics in Montréal (July 2015), at the GATE seminar in Saint-Etienne (October 2015), and at the AOH seminar in Paris (November 2015). I am grateful to Antoinette Baujard, Annie Cot, Jérôme Lallement, Joseph Mazor, and Eric Brandstedt for their feedback. The paper has also benefited from the constructive criticism of the editor of this special issue, Stefan Mann, as well as from two anonymous referees. I am solely responsible for the remaining errors and disagreements. My visit to the LSE was made possible by a mobility grant from the Swiss National Science Foundation. 


\section{REFERENCES}

Amadae, S. M. (2003). Rationalizing Capitalist Democracy. The Cold War Origins of Rational Choice Liberalism. Chicago: The University of Chicago Press.

Andel, N. (1984). “Zum Konzept Der Meritorischen Güter.” FinanzArchiv / Public Finance Analysis 42 (3), 630-48.

Arrow, K. J. (1951). Social Choice and Individual Values. New Haven: Yale University Press. Second Edition.

Auld, D. A. L., and P. C. Bing. (1971). “Merit Wants: A Further Analysis.” Finanzarchiv 30 (2), 257-65.

Backhouse, R. E., and T. Nishizawa. (2010a). "Welfare Economics, Old and New." In No Wealth but Life, 223-36. Cambridge: Cambridge University Press.

———, eds. (2010b). No Wealth but Life. Cambridge: Cambridge University Press.

Baigent, N. (1981). “Social Choice and Merit Goods.” Economics Letters 7 (1), 301-5.

Ballentine, J. G. 1972. “Merit Goods, Information, and Corrected Preferences.” Finanzarchiv $31,298-306$.

Basu, K. (1976). “Retrospective Choice and Merit Goods.” Finanzarchiv 35 (2).

Baujard, A. (2015a). “A History of Welfare Economics.” Working paper. mimeo.

-_—. (2015b). "Economic Science Vs. Welfare Economics. An Epistemological Reading of the History of Welfare Economics." Working Paper. mimeo.

Bergson, A. (1938). "A Reformulation of Certain Aspects of Welfare Economics." The Quarterly Journal of Economics 52 (2). Oxford University Press, 310-34.

Besley, T. (1988). “A Simple Model for Merit Good Arguments.” Journal of Public Economics $35,371-83$. 
Braulke, M. (1972). "Merit Goods: A Few Additional Comments." In An Anthology Regarding Merit Goods: The Unfinished Ethical Revolution in Economic Theory, edited by Wilfried Ver Eecke, 2007, 221-23. West Lafayette, Indiana: Purdue University Press.

Brennan, G. and L. Lomasky. (1983). "Institutional Aspects of 'Merit Goods' Analysis." Finanzarchiv 41 (2), 183-206.

Brennan, G., and C. Walsh, eds. (1990). Rationality, Individualism, and Public Policy. Canberra: Centre for Research on Federal Financial Relations, The Australian National University.

Buchanan, J. M. 1960. "Review: The Theory of Public Finance." Southern Economic Journal 26, 234-38.

Burrows, P. (1977). “'Efficient' Pricing and Government Interference." In An Anthology Regarding Merit Goods: The Unfinished Ethical Revolution in Economic Theory, edited by Wilfried Ver Eecke, 2007, 281-94. West Lafayette, Indiana: Purdue University Press.

Clark, J. M. (1936). “Toward a concept of social value.” In Preface to Social Economics. Essays on Economic Theory and social problems, 44-65. New York: Farrar \& Rinehart.

Clément, V., N. Moureau, and M. Vidal. 2009. "À la recherche des biens sous tutelle." L'Actualité économique, Revue d'analyse économique 85(4), 383-401.

Colm, G. (1960a). “In Defense of the Public Interest.” Social Research, 27 (1).

- - . (1960b). "The Theory of Public Finance: A Study in Public Economy. By Richard A. Musgrave." The Journal of Finance, 15 (1), 118-20.

- — (1965). "National Goals Analysis and Marginal Utility Economics." Finanzarchiv, 24 (2), 209-24.

Cooter, R. D., and J. Gordley. (1995). "The Cultural Justification of Unearned Income: An Economic Model of Merit Goods Based on Aristotelian Ideas of Akrasia and Distributive Justice." In Profits and Morality, edited by R. Cowan and M. J. Rizzo, 150-74. Chicago: The University of Chicago Press. 
Cooter, R. D., and P. Rappoport. (1984). "Were the Ordinalists Wrong About Welfare Economics?" Journal of Economic Literature, 22 (2), 507-30.

Culyer, A. J. (1971). "Merit Goods and the Welfare Economics of Coercion." Public Finance / Finances Publiques, 26 (1), 546-72.

Dasgupta, P. (2005). "What Do Economists Analyze and Why: Values or Facts?" Economics and Philosophy, 21 (2), 221-78.

Davis, J. B. (1990). "Cooter and Rappoport on the Normative." Economics and Philosophy, 6 (1): 139-46.

- - (2006). "The Turn in Economics: Neoclassical Dominance to Mainstream Pluralism?" Journal of Institutional Economics, 2 (1), 1-20.

- - (2008). "The Turn in Recent Economics and Return of Orthodoxy." Cambridge Journal of Economics 32 (3), 349-66.

De Viti de Marco, A. (1934). First Principles of Public Finance. London: Jonathan Cape. English translation from 1936.

Desmarais-Tremblay, M. (2014). "Normative and Positive Theories of Public Finance: Contrasting Musgrave and Buchanan." Journal of Economic Methodology, 21 (3), 273-89.

- - - (2015a). "A Genealogy of the Concept of Merit Wants." Forthcoming in 2017 in the European Journal of the history of economic thought.

- - . (2015b). "Musgrave, Samuelson, and the crystallization of the standard rationale for public goods." Working Paper. Based on a previous paper from 2013 titled "On the definition of Public Goods. Assessing Richard A. Musgrave's contribution."

Desreumaux, V. (2013). “Équilibre général et justice sociale : la théorie néoclassique comme philosophie politique ?" Cahiers d'économie Politique, 1(64), 75-110. 
Dowding, K. (2009). "What Is Welfare and How Can We Measure It?" In The Oxford Handbook of Philosophy of Economics, edited by H. Kinkaid and D. Ross, 511-39. New York: Oxford University Press.

D’amico, D. (2009). "Merit Goods, Paternalism and Responsibility." In Public Choice E Political Economy, 24-25.

Ege, R., and H. Igersheim. (2010). "Rawls's Justice Theory and Its Relations to the Concept of Merit Goods." European Journal of the History of Economic Thought, 17 (4), 1001-30.

Erickson, P., J. L. Klein, L. Daston, R. Lemov, T. Sturm, and M. D. Gordon. (2013). How Reason Almost Lost Its Mind. The Strange Career of Cold War Rationality. Chicago: The University of Chicago Press.

Fiorito, R., and Kollintzas, T. (2004). "Public goods, merit goods, and the relation between private and government consumption." European Economic Review, 48(6), 1367-1398.

Folkers, C. (1974). "Merit Goods: A Problem in the Normative Theory of Public Spending." In An Anthology Regarding Merit Goods: The Unfinished Ethical Revolution in Economic Theory, edited by Wilfried Ver Eecke, 2007. 253-80. West Lafayette, Indiana: Purdue University Press.

Frankfurt, H. G. (1971). "Freedom of the Will and the Concept of a Person." The Journal of Philosophy, 68 (1), 5-20.

Friedman, M. (1953). "The Methodology of Positive Economics." In Essays in Positive Economics, 3-43. Chicago: The University of Chicago Press.

Galbraith, J. K. (1958). The Affluent Society. Cambridge, MA: The Riverside Press.

Grinberg, R., and A. Rubinstein. (2005). Economic Socio-Dynamic. Berlin: Springer.

Habermas, J. (1990). Moral Consciousness and Communicative Action. Cambridge: Polity Press. 
Harsanyi, J. C. (1955). "Cardinal Welfare, Individualistic Ethics, and Interpersonal Comparisons of Utility." Journal of Political Economy, 63 (4), 309-21.

Hawi, R. (2011). "La Théorie de la justice de John Rawls à l'aune de l'économie: une reconstruction." PhD thesis, Université Paris Ouest Nanterre La Défense.

Head, J. G. (1966). “On Merit Goods.” Finanzarchiv, 25 (1), 1-29.

———. (1969). “Merit Goods Revisited.” Finanzarchiv, 28 (2), 214-25.

- - . (1988). "On Merit Wants: Reflections on the Evolution, Normative Status and Policy Relevance of a Controversial Public Finance Concept." Finanzarchiv, 46,1-37.

- - (1991). "Merit Wants: Analysis and Taxonomy." In Retrospectives on Public Finance, edited by L. Eden, 229-52. Durham: Duke University Press.

- - . (2009). "Introduction and Dedication." In Tax Reform in the 21st century. A Volume in Memory of Richard Musgrave, edited by J. G. Head and R. Krever, xi-xiii. Kluwer Law International.

Hegel, G. W. F. (1821). Elements of the Philosophy of Right. Cambridge: Cambridge University Press. 1991. Translated by H.B. Nisbet and edited by A. W. Wood.

Hochman, H. M., and J. D. Rodgers. (1969). "Pareto Optimal Redistribution." The American Economic Review, 59 (4), 542-57.

Hutt, W. H. (1934). "Economic Method and the Concept of Competition." The South African Journal of Economics, 2 (1): 1-23.

-——. (1936). Economists and the Public. London: Jonathan Cape.

_-_. (1940). "The Concept of Consumers' Sovereignty." The Economic Journal, 50 (197), 66-77.

Johansen, L. (1965). Public Economics. Amsterdam: North-Holland. 
Kirchgässner, G. (2015). "Soft paternalism, merit goods, and normative individualism." European Journal of Law and Economics, [online first].

Mackscheidt, K. (1974). "Merit Goods: Musgrave's Idea and Its Consequences." In $A n$ Anthology Regarding Merit Goods: The Unfinished Ethical Revolution in Economic Theory, edited by Wilfried Ver Eecke, 2007, 244-52. West Lafayette, Indiana: Purdue University Press.

Mann, S. (2006). "Merit Goods in a Utilitarian Framework." Review of Political Economy, 18 (4), 509-20.

Mann, S., and M. Gairing. 2012. "Does Libertarian Paternalism Reconcile Merit Goods Theory with Mainstream Economics?" Forum for Social Economics, 41 (2-3), 206-19.

Mastromatteo, G., and S. Solari. (2014). "The Idea of 'Common Good' and the Role of the State in Present Day Social Economics." Rivista Internazionale Di Scienze Sociali, 124 (1), 85-102.

Mazzola, U. (1890). "The Formation of the Prices of Public Goods." In Classics in the Theory of Public Finance, edited by R. A. Musgrave and A. T. Peacock, 37-47. London: Macmillan \& Co. 1958.

McLure, C. E. Jr. (1968). "Merit Wants: A Normatively Empty Box." Finanzarchiv 27 (3): $474-83$.

McLure, C. E. Jr. (1990). “Merit Wants.” In Rationality, Individualism, and Public Policy, edited by G. Brennan and C. Walsh, 178-85. Canberra: Centre for Research on Federal Financial Relations.

Mongin, P. (2006). "A Concept of Progress for Normative Economics." Economics and Philosophy, 22 (01), 19-54.

Munro, A. (2009). Bounded Rationality and Public Policy: A Perspective from Behavioural Economics. Springer. 
Musgrave, R.A. (1937). The Theory of Public Finance and the Concept of "Burden of Taxation". PhD dissertation, Harvard University.

——_. (1957). "A Multiple Theory of Budget Determination." Finanzarchiv, 17 (3), 333-43.

- - . (1959). The Theory of Public Finance: A Study in Public Economy. New York: McGraw Hill.

- - . (1969a). "Provision for Social Goods." In Public Economics: An Analysis of Public Production and Consumption and Their Relations to the Private Sectors., edited by J. Margolis and H. Guitton, 124-44. London: Macmillan.

- - . (1969b). "Cost-Benefit Analysis and the Theory of Public Finance." Journal of Economic Literature, 7(3), 797-806.

_——. (1970). "Pareto Optimal Redistribution: Comment." The American Economic Review, 60 (5): 991-93.

_—_. (1983). "Public Finance, Now and Then." Finanzarchiv, 41 (1), 1-13.

_——. (1987). "Merit Goods." In The New Palgrave Dictionary of Economics, edited by J. Eatwell, M. Milgate, and P. Newman, first edition, 1958-60. Palgrave.

- - (1997). "Crossing Traditions." In Zur deutschsprachigen wirtschaftswissenschaftlichen Emigration nach 1933, edited by H. Hagemann, 63-79. Marburg: Metropolis-Verlag.

- - - (1999). "Fiscal Federalism." In Public Finance and Public Choice: Two Contrasting Visions of the State, by J. M. Buchanan and R. A. Musgrave, 155-75. Cambridge, MA: MIT Press/ CESifo.

Musgrave, P. B. (2008). "Comments on two Musgravian concepts." Journal of Economics and Finance, 32(4), 340-347.

Nussbaum, M. C. (2000). Women and Human Development: The Capabilities Approach. Cambridge: Cambridge University Press. 
Pauly, M. V. (1970). "Efficiency in the Provision of Consumption Subsidies." Kyklos, 23 (1): 33-57.

Pazner, E. A. (1972). "Merit Wants And The Theory of Taxation." Public Finance / Finances Publiques, 27 (4): 460-72.

Pigou, A. C. (1932). The Economics of Welfare. London: Macmillan. $4^{\text {th }}$ edition.

Pulsipher, A. G. (1971). "The Properties and Relevancy of Merit Goods." Finanzarchiv, 30 (2): 266-86.

Racionero, M. (2000). "Optimal Redistribution with Unobservable Preferences for an Observable Merit Good." International Tax and Public Finance, 7, 479-501.

Rawls, J. (1971). A Theory of Justice. Cambridge, MA: Harvard University Press.

- - - (1982). "Social Unity and Primary Goods." In Utilitarianism and Beyond, edited by A. Sen and B. Williams, 158-85. Cambridge: Cambridge University Press.

———. (2001). Justice as Fairness. A Restatement. Cambridge: Harvard University Press.

Ritschl, H. (1931). "Communal Economy and Market Economy." In Classics in the Theory of Public Finance, edited by Richard A. Musgrave and Alan T. Peacock, 233-42. London: Macmillan.

Robbins, L. (1932). An Essay on the Nature \& Significance of Economic Science. London: Macmillan.

Roskamp, K. W. (1975). "Public Goods, Merit Goods, Private Goods, Pareto Optimum, and Social Optimum." Public Finance / Finances Publiques, 30 (1), 61-69.

Rüffer, C. (2007). Merit Goods Determined by Society Value Judgments - Political Implications for Public Participation. Support from an Empirical Analysis Concerning Environmental Goods. Stuttgart: Ibidem.

Samuelson, P. A. (1947). Foundations of Economic Analysis. Cambridge, MA: Harvard University Press. 
-_- (1954). "The Pure Theory of Public Expenditure." The Review of Economics and Statistics, 36 (4), 387-89.

Sandel, M. J. (1996). Democracy's Discontent. America in Search of a Public Philosophy. Cambridge, MA: Harvard University Press.

Sandmo, A. (1983). "Ex Post Welfare Economics and the Theory of Merit Goods." Economica, 50 (197): 19.

Sen, A. (1977). "Rational Fools: A Critique of the Behavioral Foundations of Economic Theory." Philosophy and Public Affairs, 6 (4), 317-44.

- - - (1979). "Personal Utilities and Public Judgements: Or What's Wrong with Welfare Economics." The Economic Journal, 89 (355), 537-58.

Sturn, R. (2015). "The Merits of Merit Wants." In Individual and Collective Choice and Social Welfare: Essays in Honor of Nick Baigent, edited by C. Binder, G. Codognato, M. Teschl, and Y. $\mathrm{Xu}, 289-308$. Heidelberg: Springer.

Sunstein, C. R., and R. H. Thaler. (2003). "Libertarian Paternalism Is Not an Oxymoron." The University of Chicago Law Review, 70 (4), 1159.

Taylor, C. (1982). "The Diversity of Goods." In Utilitarianism and Beyond, edited by A. Sen and B. Williams, 129-44. Cambridge: Cambridge University Press.

- - (1990). "Irreducibly Social Goods." In Rationality, Individualism, and Public Policy, edited by G. Brennan and C. Walsh, 45-63. Canberra: Centre for Research on Federal Financial Relations.

Thaler, R. H., and C. R. Sunstein. (2003). "Libertarian Paternalism." American Economic Review, 93 (2), 175-79.

Tiebout, C. M., and D. B. Houston. (1962). "Metropolitan Finance Reconsidered: Budget Functions and Multi-Level Governments." The Review of Economics and Statistics, 44 (4), 412-17. 
Tobin, J. (1970). “On Limiting the Domain of Inequality." Journal of Law and Economics, 13, 263-77.

Ver Eecke, W. (1998). “The Concept of a 'Merit Good' The Ethical Dimension in Economic Theory and the History of Economic Thought or the Transformation of Economics into Socio-Economics." Journal of Socio-Economics, 27 (1), 133-53.

———. (1999). "Public Goods: An Ideal Concept." Journal of Socio-Economics, 28 (2), 13956.

- - (2003). "Adam Smith and Musgrave's Concept of Merit Good." Journal of SocioEconomics, 31 (6), 701-20.

- - , ed. (2007). An Anthology Regarding Merit Goods: The Unfinished Ethical Revolution in Economic Theory. West Lafayette, Indiana: Purdue University Press.

-_- (2008). Ethical Dimensions of the Economy: Making Use of Hegel and the Concepts of Public and Merit Goods. Berlin: Springer-Verlag.

- - (2013). Ethical Reflections on the Financial Crisis 2007/2008: Making Use of Smith, Musgrave and Rajan. Heidelberg: Springer-Verlag.

Walsh, C. (1987). "Individual Irrationality and Public Policy: In Search of Merit/Demerit Policies." Journal of Public Policy 7 (2), 103-34.

Wiseman, J. (1960). “The Public Economy.” Economica, 27(107), 258-270. 